\title{
APLIKASI PENGENALAN WAJAH MENGGUNAKAN METODE EIGENFACE DAN JARAK EUCLIDEAN
}

\author{
Kresna Lita Maulana*), Achmad Hidayatno, dan Imam Santoso \\ Departemen Teknik Elektro, Universitas Diponegoro \\ Jl. Prof. Sudharto, SH, Kampus UNDIP Tembalang, Semarang 50275, Indonesia \\ ${ }^{*}$ E-mail: klita46@gmail.com
}

\begin{abstract}
Abstrak
Wajah merupakan salah satu identitas bagi setiap individu pada sistem biometrik. Wajah merupakan ciri unik dari setiap manusia yang dapat membedakan rupa antar manusia. Berbeda dengan manusia yang dapat mengenali wajah dengan mudah dan cepat, komputer tidak secepat dan semudah manusia. Pada komputer diperlukan suatu algoritme dalam pengenalan wajah. Pada Penelitian ini, dirancang suatu sistem pengenalan wajah menggunakan kamera web dan OpenCV yang terpasang pada Raspberry Pi 3 Model B. Masukan sistem berupa video real-time yang diperoleh dari kamera web. Metode yang digunakan pada pendeteksian wajah adalah metode Viola-Jones dan dalam pengenalan wajah digunakan metode eigenface dan jarak euclidean. Terdapat 5 responden yang diambil citra wajahnya sebagai database. Hasil yang diperoleh dari sistem ini adalah nama dari setiap responden yang terdapat pada database. Berdasarkan hasil pengujian pada kondisi dalam ruangan dihasilkan rata-rata akurasi sebesar 99,8\%, sedangkan pada kondisi luar ruangan dihasilkan rata-rata akurasi sebesar $93,8 \%$. Pada pengujian citra wajah yang diberi derau salt \& pepper dengan kepadatan derau 0,001 dan 0,01 didapatkan bahwa program mampu mengenali wajah dengan benar. Program mampu mengenali wajah dengan benar pada citra yang dirotasi sebesar 10 derajat.
\end{abstract}

Kata kunci: Pengenalan wajah, algoritme eigenface, jarak euclidean, metode Viola Jones, OpenCV, Raspberry Pi.

\begin{abstract}
Facial recognition is one of the biometric systems. Face is the hallmark of every human being who can distinguish between human beings. Face recognition is widely used for identification systems on security systems and attendance machines. In this Research, designed a face recognition system using web camera and OpenCV mounted on Raspberry Pi 3 Model B. Input system of video obtained from camera. The method used on face detection is Viola-Jones method and in face recognition used eigenface and euclidean distance. Face image capture of 55 images from 5 people using web camera. The image is stored in a folder as a database. The result obtained from this system is the name of each respondent in the database. In the test also performed a system endurance test against salt \& pepper and image rotation attacks. Based on the test result on indoor condition, the average value of accuracy is $99,8 \%$ and in outdoor condition, the average value of accuracy is $93,8 \%$. Based on the image test of salt \& pepper attack it was found that the program was able to correctly recognize the face at 0.001 and 0.01 noise density. Image testing against rotational attacks found that the program is only able to detect faces on rotated images of 10,15 , and 20 degrees. The program is not resistant to rotational attacks so it goes wrong recognizing the face.
\end{abstract}

Keywords: face recognition, eigenface algorithm, euclidean distance, Viola Jones method, OpenCV, Raspberry Pi.

\section{Pendahuluan}

Pengenalan wajah dalam beberapa tahun terakhir semakin berkembang dengan adanya kemajuan software maupun hardware, identifikasi seseorang berdasarkan biometrik telah berkembang dengan pesat. Metode pengenalan identitas seseorang yang banyak digunakan diantaranya berdsarkan nomor identitas unik seperti kartu identitas atau berdasrkan ingatan terhadap suatu sandi rahasia[14]. Metode tersebut banyak memeliki kekurangan seperti hilangnya kartu identitas atau lupa sandi dari ingatan seseorang. Ada dua jenis biometrik di antaranya adalah physiological (iris mata, wajah dan sidik jari) dan behavioural (suara dan tulisan tangan) [13]. Pengenalan wajah merupakan suatu pengenalan pola (pattern recognition) yang khusus untuk kasus wajah. Eigenface adalah suatu metode pengenalan wajah yang berdsarkan pada algoritme Principal Component Analysis (PCA). Principal Component Analysis yang merupakan suatu metode ekstraksi ciri yang mampu mengidentifikasi ciri tertentu yang merupakan karakteristik suatu citra (dalam hal ini adalah wajah) [14]. Liton dan Abdulla [15] merancang sebuah program untuk mengenali wajah menggunakan algoritme eigenface dengan 
membandingkan citra wajah uji dan citra wajah pada database menggunakan matlab.

Pada Penelitian ini dirancang suatu sistem pengenalan wajah dengan menggunakan kamera web yang akan tersambung secara langsung dengan komputer mini Raspberry Pi sebagai perangkat pemroses. Sebelum melakukan pengenalan diperlukan pengambilan citra sebagai database. Citra pada database disimpan dengan format .JPEG. Masukan sistem merupakan video secara real-time. Metode pengenalan wajah yang digunakan adalah Eigenface dan jarak Euclidean. Selain itu, digunakan algoritme haar cascade yang berfungsi untuk mendeteksi wajah pada video. Hasil yang diperoleh merupakan nama dari seseorang yang sedang diuji secara real-time. Terdapat pengujian ketahanan sistem terhadap serangan-serangan salt \& pepper dan rotasi. Inputan pada pengujian ketahanan adalah citra berformat .JPEG.

\section{Metode}

\subsection{Blok Diagram Aplikasi Pengenalan Wajah}

Sistem yang dirancang adalah sebuah program untuk mendeteksi dan mengenali wajah manusia. Jika terdeksi adanya wajah manusia, maka sistem ini akan melanjutkan mengenali wajah yang direkam oleh kamera. Wajah akan dikenali berdasarkan pada nilai jarak antara wajah yang direkam oleh kamera dengan wajah di database. Sebelum melakukan pengenalan wajah diperlukan citra wajah yang digunakan sebagai database sehingga wajah bisa dikenali dengan benar. Pengambilan citra wajah sebagai database dilakukan menggunakan kamera web.

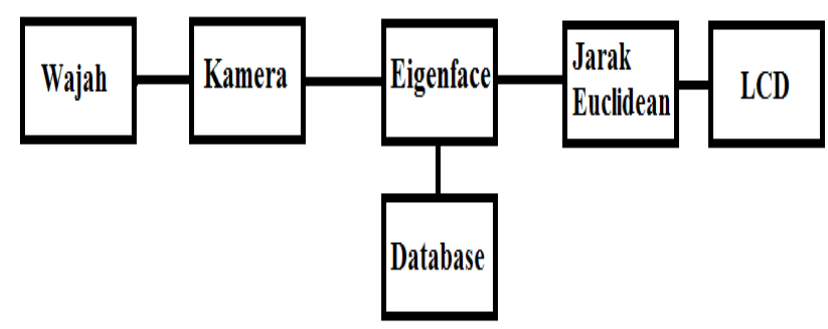

Gambar 1. Diagram blok sistem pengenalan wajah

\subsection{Bagian Masukan}

Pada bagaian ini kamera web memeiliki dua fungsi sekaligus. Fungsi yang pertama, kamera dapat digunakan sebagai alat untuk mengambil citra wajah jika diinginkan untuk pengambilan citra sebagai database. Fungsi yang kedua, kamera digunakan sebagai alat merekam suatu video sebagai inputan. Pada pengenalan wajah, kamera akan merekam video secara real-time yang kemudian masukan dari kamera akan diproses oleh Raspberry Pi. Kamera web ini memiliki port keluaran berupa USB (Universal Serial Bus) yang disambungkan ke Raspberry Pi.

\subsection{Bagian Pengolah}

Raspberry Pi adalah komponen yang berfungsi sebagai pengolah. Raspberry Pi melakukan empat proses, yakni proses pengambilan citra wajah, preprocessing, deteksi letak wajah, dan pengenalan wajah. Pada saat melakukan pengenalan wajah peratama-tama video yang diambil secara real-time oleh kamera akan diperikasa apakah pada video terdapat wajah atau tidak. Jika terdapat objek yang merupakan wajah, maka objek tersebut akan langsung dilakukan proses pengenalan. Jika pada video tidak terdeteksi adanya wajah, maka sistem tidak akan melakukan pengenalan.

\subsubsection{Proses Deteksi Wajah}

Bagian ini berfungsi untuk mendeteksi wajah dari video yang diambil oleh kamera. Deteksi wajah ini menggunakan suatu library yang terdapat pada OpenCV, melalui API (Application Programming Interface) $\mathrm{C}++$ bernama cv2.CascadeClassifier. Senarai tersebut berfungsi untuk mendeteksi objek yang direkam oleh kamera. Pada pendeteksian wajah maka digunakan file XML yang berisi data penglasifikasi wajah tampak dari depan atau frontal face. Setelah mengetahui apa yang akan dideteksi maka dilakukan pendeteksian wajah menggunakan fungsi library cv2.detectMultiScale. Senarai ini berfungsi untuk menedeteksi wajah dari berbagai ukuran pada video.

\subsubsection{Proses Pengambilan Citra Wajah}

Proses pengambilan citra wajah sebagai database akan dilakukan diawal sebelum pengujian dilakukan. Pengambilan citra dilakukan di dalam ruangan dengan pencahayaan yang cukup. Pada pengambilan citra wajah diambil sebanyak 11 citra wajah. Pada perancangan ini, citra wajah diambil menggunakan kamera web. Responden yang diambil pada perancangan ini ada 5 responden sehingga jumlah citra wajah untuk database ada sebanyak 55 citra wajah. Pada pengambilan citra wajah dilakukan pendeteksian wajah terlebih dahulu. Jika pada video terdapat wajah maka, program akan memotret wajah tersebut. Pada saat wajah dipotret oleh kamera dilakukan proses preprocessing pada citra tersebut. Tahapan dalam preprocessing di antaranya adalah mengubah ukuran jumlah piksel pada citra, normalisasi intensitas menggunakan perataan histogram, dan memotong citra wajah yang terdeteksi menjadi persegi.

\subsubsection{Proses Pengenalan Wajah}

Pengenalan wajah dilakukan setelah didapatkan database yang berisi citra wajah dari responden. Pada tahap pengenalan digunakan kamera web sebagai inputan. Terdapat tujuh library pada perancangan program pengenalan wajah, yaitu PIL, numpy, scipy, os, OpenCV, 
sys, dan glob. Setiap library memiliki fungsi yang berbeda-beda.

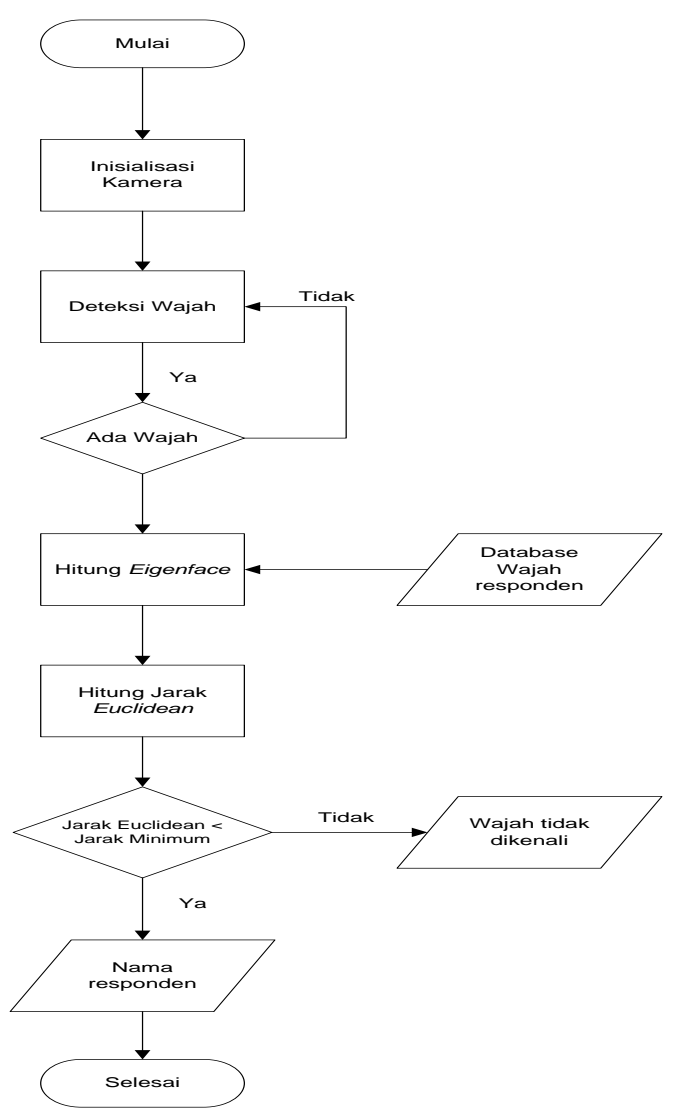

Gambar 2. Diagram alir pengenalan wajah.

Secara matematis langkah pertama dalam pengenalan wajah adalah membuat suatu himpunan $S$ yang terdiri dari citra-citra wajah sebagai database.

$S=\left\{\Gamma_{1}, \Gamma_{2}, \Gamma_{3}, \ldots, \Gamma_{M}\right\}$

Setiap citra wajah pada database direpresentasikan sebagai $\Gamma_{1}, \Gamma_{2}, \Gamma_{3}, \ldots, \Gamma_{M}$ dengan $M$ adalah jumlah citra wajah.Langkah kedua adalah mendapatkan niali rata-rata dari citra wajah pada database dengan rumus:

$\Psi=\frac{1}{M} \sum_{i=1}^{M} \Gamma_{i}$

Langkah ketiga adalah mencari selisih $(\Phi)$ antara citra di dalam database $\left(\Gamma_{i}\right)$ dengan nilai rata-rata $\Psi$.

$\Phi_{i}=\Gamma_{i}-\Psi$

Langkah keempat adalah menghitung nilai matriks kovarian (C) karena secara matematis principal component dari suatu data adalah eigenvector dari matriks kovarian. Principal Component Analysis akan mencari sekumpulan vektor yang menggambarkan secara signifikan sebuah variasi data:
$C=\frac{1}{M} \sum_{n=1}^{M} \Phi_{\mathrm{n}} \Phi_{\mathrm{n}}^{\mathrm{T}}=A A^{T}$

Dimana $A=\left[\Phi_{1}, \Phi_{2}, \ldots, \Phi_{\mathrm{M}}\right]$ dan $A^{T}$ adalah matriks transpose $A$.Langkah kelima menghitung eigenvalue $(\lambda)$ dan eigenvector (v) dari matriks kovarian (C).

$(C-\lambda I)=0$ atau $(\lambda I-C)=0$

Langkah keenam adalah mencari nilai eigenface $(\mu)$.

$\mu_{i}=\sum_{k=1}^{M} v_{l k} \Phi_{k}$

Dimana $v$ adalah eigenvector dan $\Phi_{k}$ adalah selisih antara setiap training image $\Gamma_{i}$ pada database dengan nilai ratarata citra wajah $\Psi$. Sebuah citra wajah uji atau test face $\left(\Gamma_{\text {new }}\right)$ akan dilakukan proses pengenalan. Citra wajah baru tersebut harus dilakukan proses perhitungan untuk mendapatkan eiganface. Setelah didapatkan nilai citra wajah baru atau test face barulah dilakukan pengenalan wajah dengan membandingkan nilai tersebut menggunakan jarak euclidean.

$$
\begin{aligned}
& \mu_{\text {new }}=v\left(\Gamma_{\text {new }}-\Psi\right) \\
& d(x, y)=\sqrt{\sum_{i=1}^{M}\left(\left(x_{i}\right)-\left(y_{i}\right)\right)^{2}}
\end{aligned}
$$

\subsection{Bagian Keluaran \\ 2.4.1. Layar LCD}

Layar LCD berfungsi untuk menampilkan GUI (Graphical User Interface) dan melihat video secara realtime. Pada GUI tersebut, pengguna dapat memilih untuk mengambil data berupa citra wajah sebagai database atau menguji program untuk melakukan pengenenalan wajah. Apabila pengguna ingin melakukan pengambilan citra wajah untuk disimpan sebagai database maka pengguna dapat mengklik button ambil citra

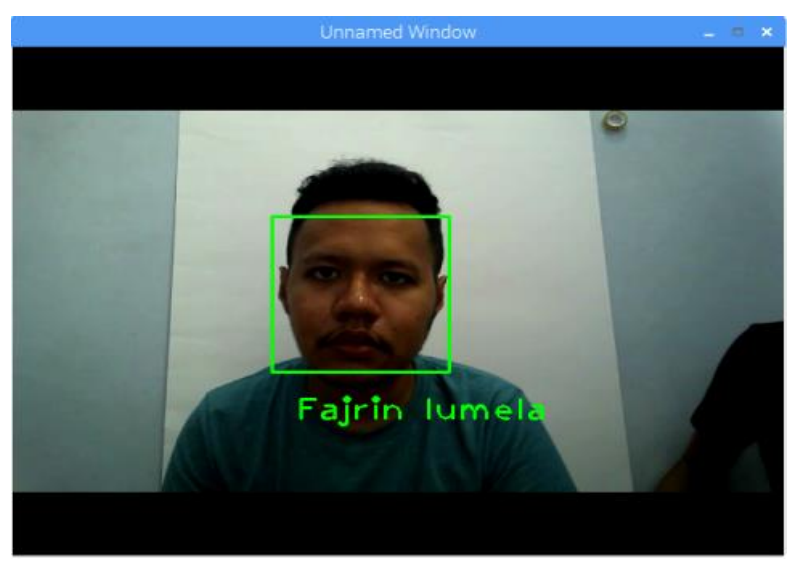

Gambar 3. Tampilan jenedela hasil pengenalan pada LCD. 


\subsection{Perancangan Perangkat Lunak}

Perangkat lunak yang digunakan adalah Python versi 3.6 dan OpenCV versi 3.2. Program dibuat menggunakan aplikasi anaconda dan spyder 3.1.4. Setelah seluruh program selesai maka program hanya perlu dipindahkan ke Raspberry Pi. Python sudah terpasang secara langsung pada Raspberry Pi, sedangkan OpenCV harus diunduh dan dipasang terlebih dahulu pada Raspberry Pi. Sistem operasi yang digunakan pada Raspberry Pi adalah raspbian jessie. Library yang digunakan pada perancangan program di antaranya adalah OpenCV, numpy, scipy, tkinter, PIL, os, sys, runpy dan lain sebagainya. Library untuk membuat GUI adalah tkinter. Pada saat menjalankan program digunakan sebuah aplikasi yang beranama idle.

\subsection{Perancangan Perangkat Keras}

Perangkat keras yang digunakan dalam melakukan pengenalan wajah di antaranya adalah Layar LCD, Kamera web, Raspberry $\mathrm{Pi}$, keyboard, mouse, kabel HDMI, dan Micro SD. Rangkaian keseluruhan alat ditunjukan pada Gambar 4. Raspberry Pi diberi catu daya yang bersumber dari USB charger. Micro SD yang digunakan pada perancangan ini berkapasitas 16GB. Layar LCD yang digunakan pada perancangan ini berukuran 21 inch. Rangkaian ini juga digunakan untuk melakukan pengambilan citra wajah.

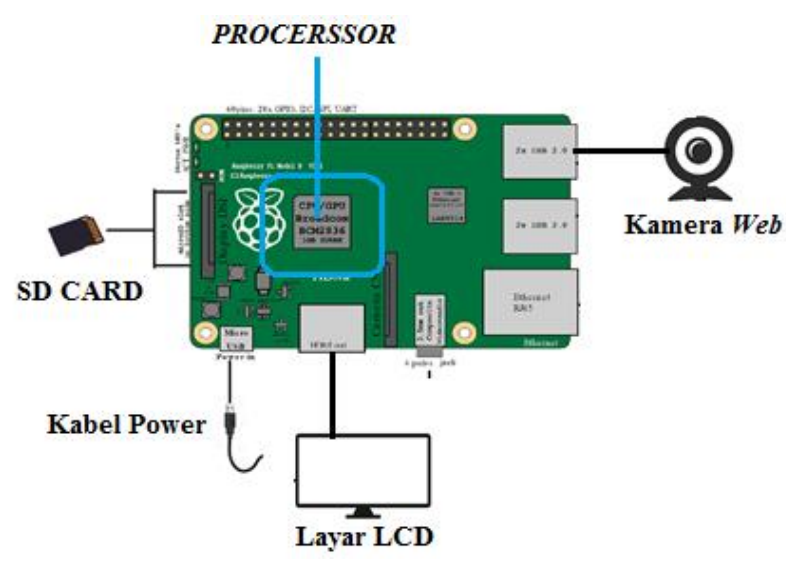

Gambar 4. Skematik raspberry Pi 3 Model B.

\section{Hasil dan Analisa}

Pada bab ini dibahas berbagai pengujian yang dilakukan pada program yang telah dirancang dan menganalisis hasil pengujian. Masukan yang digunakan adalah video real-time. Pengujian dilakukan di dalam dan luar ruangan. Pada saat di dalam ruangan digunakan pengujian menggunakan latar belakang karton berwarna putih. Pengujian di luar ruangan dilakukan pada saat siang hari. Posisi kamera hanya mengambil bagian wajah tampak depan saja. Sebelum pengujian, dilakukan pengambilan citra wajah sebanyak 11 citra. Jumlah responden pada penelitian ini adalah 5 orang. Pengujian yang dilakukan dibagi menjadi lima bagian. pertama adalah pengujian pengambilan citra wajah, yaitu pengujian yang bertujuan untuk mengambil citra pada bagian wajah saja. Pada pengambilan citra wajah dilakukan proses preprocessing oleh program. Kedua adalah pengujian dalam ruangan, yaitu pengujian yang bertujuan untuk mengenali wajah seseorang di dalam ruangan. Hasil yang diperoleh dari pengenalan wajah kondisi di dalam ruangan akan dianalisis. Ketiga adalah pengujian luar ruangan, yaitu pengujaian yang bertujuan untuk mengenali wajah seseorang di luar ruangan. Hasil yang diperoleh dari pengenalan wajah kondisi di luar ruangan akan dianalisis. Keempat adalah pengujian wajah dengan individu yang tidak ada di dalam database, yaitu pengujian pengenalan dengan menggunakan responden yang tidak ada di database. Pengujian wajah dengan citra yang diberi serangan-serangan, yaitu pengujian pengenalan dengan citra yang sudah diberi derau salt \& papper dan rotasi citra.

\subsection{Pengujian Pengambilan Citra Wajah}

Pengujian pengambilan citra wajah bertujuan untuk mengambil citra wajah yang dideteksi oleh program kemudian di lakukan proses preprocessing dan menyimpan citra tersebut kedalam folder database.

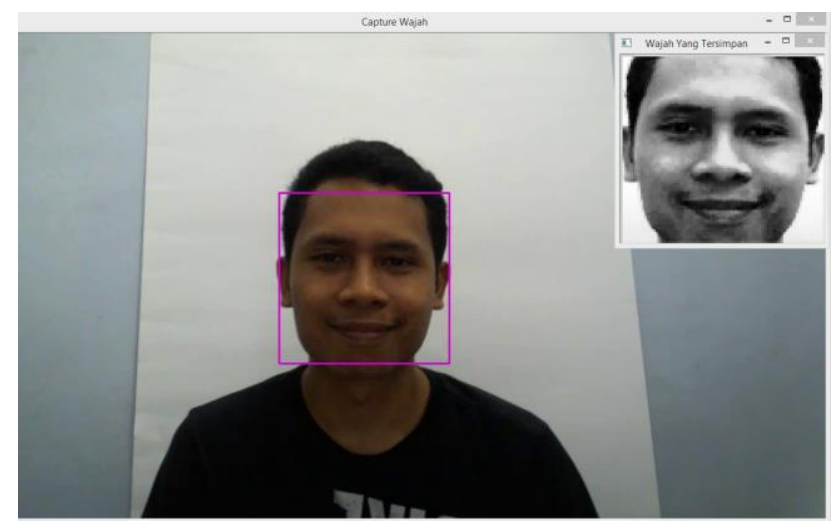

Gambar 5. Pengujian pengambilan citra sebagai database

Tahap pertama sebelum dilakukan proses preprocessing adalah mengaktifkan kamera. Pada saat kamera aktif muncul sebuah jendela yang menampilkan video hasil rekaman kamera secara real-time. Tahap kedua adalah program akan mendeteksi keberadaan wajah. Pada saat terdapat wajah yang ditangkap kamera maka secara otomatis kamera memotret wajah tersebut dan dihasilkan citra wajah yang sudah dilakukan preprocessing. Proses yang dilakukan dalam preprocessing adalah mengubah ukuran citra, mengubah warna citra dari RGB menjadi aras keabuan. Pada saat citra berwarna sudah diubah menjadi aras keabuan dilakukan perataan histogram untuk mendapatkan citra dengan daerah tingkat keabuan yang 
terdistribusi secara merata. Citra yang diambil oleh kamera disimpan di suatu folder dengan format .JPEG berukuran $100 \times 100$ piksel. Gambar 5, menunjukan proses pengambilan citra wajah sebagai database.

\subsection{Pengujian Pengenalan Kondisi Dalam Ruangan}

Pengujian pengenalan wajah di dalam ruangan menggunakan inputan yang berasal dari kamera web secara real-time. Rosolusi yang digunakan adalah $640 \times 480$ piksel. Pengenalan wajah di dalam ruangan digunakan latar belakang karton yang berwarna putih. Pada saat kamera aktif maka program akan mendeteksi keberadaan wajah. Apabila terdapat wajah maka program akan menandai wajah tersebut dengan persegi berwarna hijau. Pada persegi hijau tersebut terdapat nama dari wajah yang dikenali. Pengujian dilakukan selama 10 detik dengan posisi wajah tampak dari depan. Pada saat pengujian akan terlihat nama dari wajah yang dikenali dan nilai jarak euclidean pada python shell. Nilai jarak euclidean akan berubah-ubah karna program terus menghitung secara real-time. Analisis yang dilakukan pada pengenalan wajah kondisi dalam ruangan adalah dengan membandingkan waktu pengujian dengan wajah yang dikenali. Video pengujian memiliki frame rate sebesar 15 frame per detik. Pengujian di luar ruangan memiliki jarak euclidean minimum sebesar 4500 yang diatur sebelum melakukan pengujian.

Tabel 1. Hasil pengujian akurasi pengenalan wajah kondisi dalam ruangan seluruh responden

\begin{tabular}{ccccccc}
\hline Responden & $\begin{array}{c}\text { Jumlah } \\
\text { orang }\end{array}$ & $\begin{array}{c}\text { True } \\
\text { Positive }\end{array}$ & $\begin{array}{c}\text { False } \\
\text { Negative }\end{array}$ & $\begin{array}{c}\text { False } \\
\text { Positive }\end{array}$ & $\begin{array}{c}\text { True } \\
\text { Negative }\end{array}$ & Akurasi \\
\hline FL & 1 & 142 & 1 & 0 & 0 & $99 \%$ \\
KR & 1 & 143 & 0 & 0 & 0 & $100 \%$ \\
YG & 1 & 143 & 0 & 0 & 0 & $100 \%$ \\
FA & 1 & 143 & 0 & 0 & 0 & $100 \%$ \\
MJ & 1 & 143 & 0 & 0 & 0 & $100 \%$ \\
\hline
\end{tabular}

Berdasarkan Tabel 1, setiap responden memiliki akurasi yang baik untuk kondisi dalam ruangan. Tingkat akurasi yang tinggi disebabkan intensitas cahaya pada saat pengambilan wajah sebagai database dan pada saat pengujian adalah sama. Pada saat pengujian setiap responden melakukan beberapa perubahan ekspresi wajah seperti tersenyum dan menaikan alis. Perubahan ekspresi tidak berpengaruh pada pengenalan wajah untuk didalam ruangan dengan tingkat intensitas cahaya yang sama. Pada Tabel 4.2 akurasi tertinggi adalah $100 \%$ dan akurasi terendah adalah $99 \%$. Nilai true positive responden KR, YG, FA, dan MJ adalah 143 yang artinya wajah dikenali dengan benar sebanyak 143 kali selama proses pengujian berlangsung. Nilai false negative pada responden FL adalah 1 yang artinya wajah salah dikenali sebanyak 1 kali selama proses pengujian berlangsung. Pada saat pengujian seluruh responden program berhasil melakukan deteksi wajah dengan baik. Program tidak mendeteksi objek selain wajah sehingga nilai true negative adalah nol

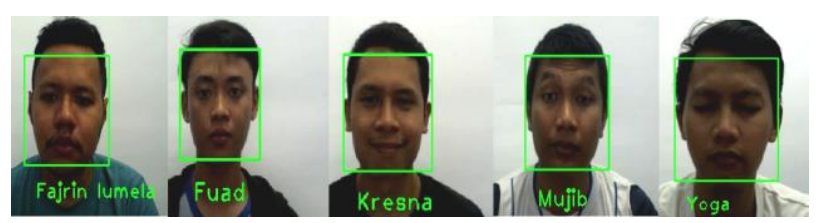

Gambar 6. Hasil pengujian pengenalan wajah kondisi dalam ruangan yang dikenali dengan benar

\subsection{Pengujian Pengenalan Kondisi Luar Ruangan Perindividu}

Pengujian pengenalan kondisi luar ruangan merupakan pengujian yang dilakukan dengan memanfaatkan cahaya matahari. Pada pengujian ini kondisi luar ruangan sedang dalam keadaan cerah. Pengujain dilakukan pada waktu sore hari dengan tingkat intensitas cahaya matahari yang berubah-ubah. Pada pengujian ini akan dianalisis tingkat akurasi pengenalan setiap individu. Pengujian dilakukan selama 10 detik dengan posisi wajah tampak dari depan. Video pengujian memiliki frame rate sebesar 15 frame per detik. Rosulis video yang digunakan adalah $640 \times 480$ piksel. Pada pengujian ini setiap responden juga melakukan perubahan pada ekspresi wajah, seperti menaikan alis, tersenyum, dan kaget. Kinerja program akan dilihat berdasarkan akurasi dari pengenalan wajah setiap individu. Pengujian di luar ruangan memiliki jarak euclidean minimum sebesar 5500 yang diatur sebelum melakukan pengujian.

Tabel 2. Hasil pengujian akurasi pengenalan wajah kondisi luar ruangan seluruh responden

\begin{tabular}{ccccccc}
\multirow{2}{*}{ Responden } & $\begin{array}{c}\text { Jumlah } \\
\text { orang }\end{array}$ & $\begin{array}{c}\text { True } \\
\text { Positive }\end{array}$ & $\begin{array}{c}\text { False } \\
\text { Negative }\end{array}$ & $\begin{array}{c}\text { False } \\
\text { Positive }\end{array}$ & $\begin{array}{c}\text { True } \\
\text { Negative }\end{array}$ & Akurasi \\
\hline FL & 1 & 143 & 3 & 0 & 0 & $97 \%$ \\
KR & 1 & 125 & 18 & 0 & 0 & $87 \%$ \\
YG & 1 & 141 & 2 & 0 & 0 & $98 \%$ \\
FA & 1 & 125 & 18 & 0 & 0 & $87 \%$ \\
MJ & 1 & 143 & 0 & 0 & 0 & $100 \%$ \\
\hline
\end{tabular}

Berdasarkan Tabel 2, nilai true positive pada responden MJ adalah 143 yang artinya wajah dikenali dengan benar sebanyak 143 kali selama proses pengujian berlangsung. Nilai false negative pada responden $\mathrm{MJ}$ adalah 0 yang artinya tidak ada wajah yang salah dikenali selama proses pengujian berlangsung. Akurasi terendah pada pengujian di luar ruangan adalah $87 \%$. Penyebab dari kesalahan pengenalan adalah perubahan ekspresi wajah dari responden KR dan FA. Transisi perubahan ekspresi wajah dari kedua responden menjadi penyebab utama kesalahan dalam pengenalan. Jumlah frame dari setiap video adalah 143 frame. Pada saat pengujian program tidak mendeteksi objek selain wajah sehingga nilai dari true negative untuk 
seluruh responden adalah nol. Gambar 8, menunjukan kesalahan pada pengenalan wajah yang disebabkan apabila terjadi perubahan ekspresi pada wajah.

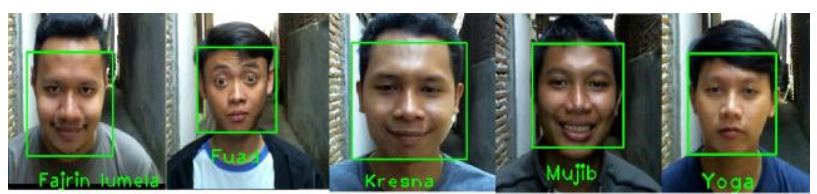

Gambar 7. Hasil pengujian pengenalan wajah kondisi luar ruangan yang dikenali dengan benar

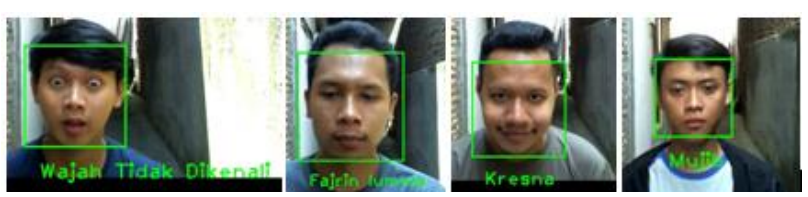

Gambar 8. Hasil pengujian pengenalan wajah kondisi luar ruangan yang salah dikenali

\subsection{Pengujian Pengenalan Wajah Individu yang Tidak Ada Di dalam Database}

Pengujian ini dilakukan oleh tiga individu yang tidak terdapat pada database. Pada pengujain ini masukan berupa video yang sudah direkam menggunakan kamera. Jarak minimum pada pengujian kali ini adalah 4500 . Apabila wajah memiliki nilai jarak lebih dari 4500 maka wajah akan dikategorikan sebagai 'wajah tidak dikenali'. Video pada pengujian berdurasi 10 detik dengan frame rate sebesar 15 frame per detrik
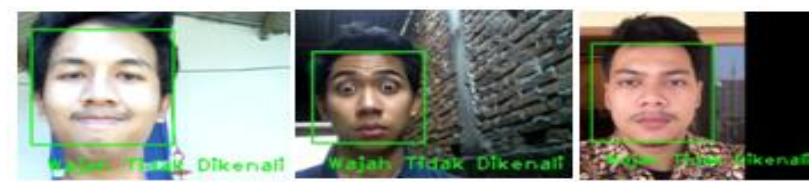

Gambar 9. Hasil pengujian akurasi wajah pada individu yang tidak ada di dalam database

Tabel 3. Hasil pengujian akurasi wajah pada individu yang tidak ada di dalam database

\begin{tabular}{ccccccc}
\hline $\begin{array}{c}\text { Nama } \\
\text { responden }\end{array}$ & $\begin{array}{c}\text { Jumlah } \\
\text { orang }\end{array}$ & $\begin{array}{c}\text { True } \\
\text { Positive }\end{array}$ & $\begin{array}{c}\text { False } \\
\text { Negative }\end{array}$ & $\begin{array}{c}\text { False } \\
\text { Positive }\end{array}$ & $\begin{array}{c}\text { True } \\
\text { Negative }\end{array}$ & Akurasi \\
\hline IK & 1 & 143 & 0 & 0 & 0 & $100 \%$ \\
RQ & 1 & 141 & 2 & 0 & 0 & $98 \%$ \\
RZ & 1 & 143 & 0 & 0 & 0 & $100 \%$ \\
\hline
\end{tabular}

Tabel 3, menunjukan bahwa ketiga responden tersebut berhasil tidak dikenali karena wajah ketiga responden tidak terdapat pada database. Responden RQ sempat dikanali sebagai responden YG pada detik kedelapan pada saat ekspresi wajah dari responden RQ menaikan alisnya.

\subsection{Pengujian Pengenalan Wajah yang Diberi Derau Salt \& Pepper}

Pada pengujian ini responden yang digunakan adalah sebanyak lima. Derau salt \& papper berupa darau yang menyerupai titik-titik garam dan merica. Pada citra warna RGB, maka deraunya berupa titik-titik denagn warna red, green, dan blue. Kepadatan derau yang digunakan pada percobaan ini adalah 0,001, 0,01, dan 0,1.

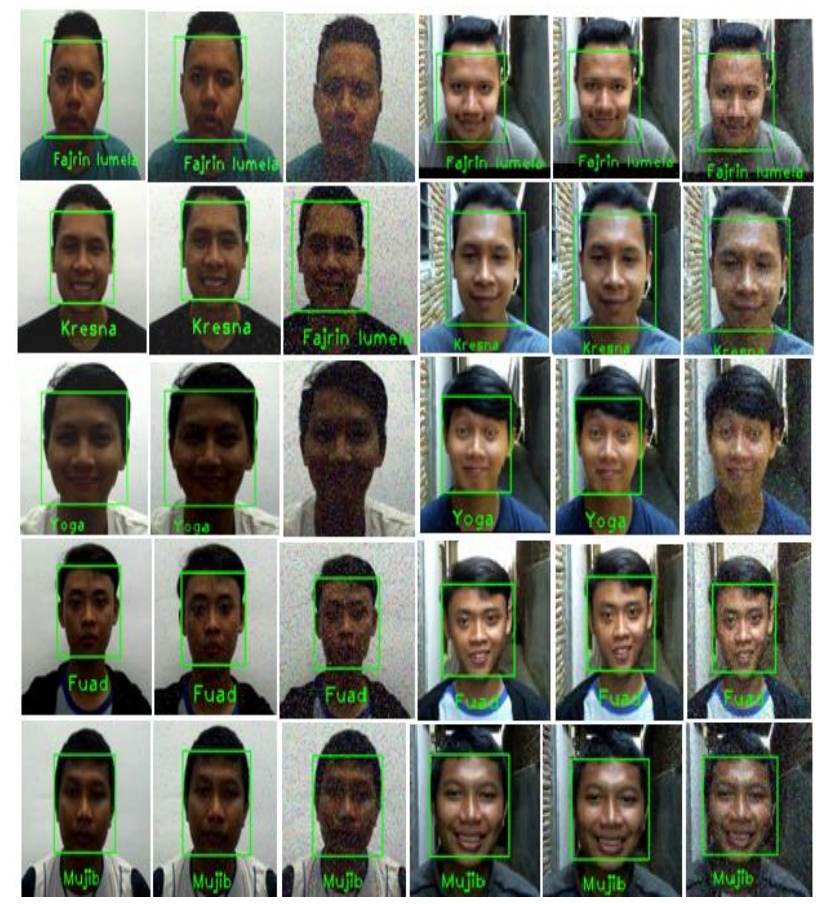

Gambar 10. Hasil pengujian pengenalan wajah dengan derau salt \& pepper $(0,001,0,01,0,1)$ pada kondisi dalam dan luar ruangan

Gambar 10, memperlihatkan hasil pengenalan pada citra berderau salt \& pepper. Pada saat nilai kepadatan derau adalah 0,001 dan 0,01 didapatkan bahwa program mampu mengenali kelima responden dengan benar. Pada pengujian ini dengan kepadatan deerau 0,1 program hanya mampu mengenali tiga responden.

\subsection{Pengujian Pengenalan Wajah Pada Citra yang Dirotasi}

Pada pengujian dengan serangan rotasi citra, citra wajah akan dirotasi dengan 4 sudut kemiringan yaitu 10, 15, 20 dan 25 derajat. Pada pengujian ini akan dilihat kinerja sistem dalam mendeteksi dan mengenali wajah pada sebuah citra. 


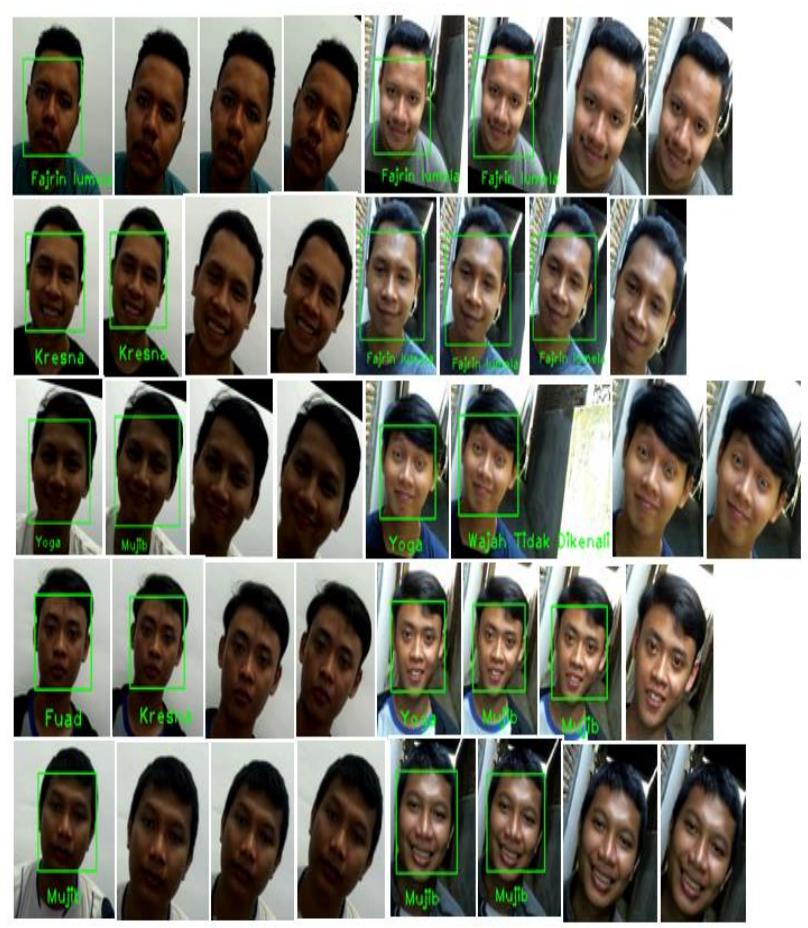

Gambar 11. Hasil pengujian pengenalan wajah dengan serangan rotasi citra responden fajrin

Gambar 11, memperlihatkan bahwa serangan rotasi citra mempengaruhi hasil pengenalan wajah. Tidak hanya memepengaruhi hasil dari pengenalan wajah, citra yang dirotasi juga menyebabkan algoritme haar cascade tidak bekerja dengan baik. . Hasil pengenalan wajah dengan sudut kemiringan 10 derajat untuk kondisi dalam ruangan memiliki akurasi $100 \%$. Pada saat sudut kemiringan 20 dan 25 derajat algoritme haar cascade tidak dapat mendeteksi adanya wajah pada citra. Pada kondisi luar ruangan algoritme haar cascade mampu mendeteksi wajah pada sudut kemiringan 10, 15, dan 20 derajat. Program mengalami salah mengenali pada kondisi luar ruangan dengan sudut kemiringan 10, 15, dan 20 derajat. Pada sudut 25 derajat algoritme haar cascade tidak mampu mendeteksi adanya wajah sehingga batas sudut yang dapat di deteksi dengan menggunakan algoritme haar cascade adalah 20 derajat.

\section{Kesimpulan}

Pada pengenalan wajah kondisi dalam ruangan diperoleh akurasi sebesar $99 \%$ dan $100 \%$. Pada pengenalan wajah kondisi luar ruangan diperoleh akurasi tertinggi sebesar $100 \%$ untuk responden MJ, sedangkan hasil terendah adalah $87 \%$ untuk responden KR dan FA. Program berhasil tidak mengenalai wajah pada pengujian individu yang tidak ada di dalam database. Pengujian pengenalan wajah untuk citra berderau salt \& pepper dengan nilai kepadatan 0,001 dan 0,01 didapatkan bahwa program mampu mengenali kelima responden dengan benar. Pada pengujian dengan kepadatan derau 0,1 program hanya mampu mengenali tiga responden. Pada pengujian rotasi citra dengan sudut kemiringan 10 derajat pada kondisi dalam ruangan didapatkan bahwa program mampu mengenali kelima responden dengan benar, sedangkan saat sudut kemiringan 20 dan 25 derajat algoritme Haar cascade tidak dapat mendeteksi adanya wajah pada citra. Penelitian ini dapat dikembangkan lebih lanjut dengan membandingkan penelitian ini dengan metode pengenalan wajah yang lain seperti LBPH, fisherface, LDA, dan lain sebagainya agar diketahui metode terbaik dalam pengenalan wajah . Pada penelitian selanjutnya dapat menambahkan variasi ekspresi dan posisi wajah pada pengujian pengenalan.

\section{Referensi}

[1] P. E. Diah. "Pengenalan Wajah Menggunakan Metode Principal Component Analysis (PCA) Untuk Aplikasi Sistem Keamanan Rumah," 2013.

[2] Immanuela P. Saputro, Ernawati, dan B. Yudi Dwiandiyanta, "Pengenelan Ekspresi Wajah Menggunakan Wavelet Gabor dan Backpropagation," Jurnal Elektro, vol. 8, no. 2, Oktober, 2015.

[3] Febrinata, Kaziz, "Simulasi dan Analisis Multiple Object Tracking Berbasis Citra dengan Metode Hierarchical Particle Filter," Tugas Akhir, Telkom University, 2013.

[4] Putra, Darma, Pengolahan Citra Digital. Depok: Andi Offset, 2010

[5] S. N. Candra. "Mengubah Citra Berwarna Menjadi Gray-Scale dan Citra Biner," Jurnal Teknologi Informasi Dinamik, vol. 16, no. 1, Januari, 2011.

[6] A. F. Riza, "Pengenalan Pola Tanda Tangan dengan Menggunakan Metode Principal Component Analysis (PCA)," Tugas Akhir, Universitas Dian Nuswantoro, 2013.

[7] H. K. Adrian "Perancangan Sistem Pengenal Garis Utama Telapak Tangan Pada Sistem Presensi Menggunakan Metode Principal Component Analysis (PCA) dan Jarak Euclidean," Jurnal Transient, vol. 4, no. 1, Maret, 2015.

[8] M. F. Eko. "Implementasi Metode Median Filter dan Histogram Equalization Untuk Perbaikan Citra Digital," Jurnal Pelita Informatika, vol. 16, no. 3, Juli, 2017.

[9] Harris Simaremare dan Agung Kurniawan. "Perbandingan Akurasi Pengenalan Wajah Menggunakan Metode LBPH dan Eigenface dalam Mengenali Tiga Wajah Sekaligus secara Real-Time," Jurnal Sains, Teknologi dan Industri, vol. 14, no. 1, Desember, 2016.

[10] Dulal Chakraborty, Sanjit Kumar Saha, dan Md. AlAmin Bhuiyan, "Face Recognition using Eigenvector and Principle Component Analysis," international Journal of Computer Applications, vol. 50, no. 10, Juli, 2012. 
[11] Y. S. Nimas, "Perbandingan Ukuran Jarak Pada Proses Pengenalan Wajah Berbasis Principal Component Analysis (PCA)," Tugas Akhir, Institut Teknologi Sepuluh Nopember, 2011.

[12] P. Viola dan M. Jones, "Rapid Object Detection using a Boosted Cascade of Simple Features," Conf. Comput. Vis. PATTERN Recognit., 2001.

[13] S. Y. Bertua Frans. "Sistem Pengenalan Wajah Menggunakan Metode Principal Component Analysis (PCA) dan Jaringan Syaraf Tiruan," Jurnal Transmisi, vol. 15 , no. $3,2013$.
[14] Wicaksono, Galih. "Sistem Identifikasi Garis Utama Telapak Tangan Menggunakan Metode Principal Component Analysis (PCA) dan Jarak Euclidean," Jurnal Transient, vol. 3, no. 1, Maret, 2014.

[15] P.C Liton dan S.A Abdulla, "Face Recognition Using Principal Component Analysis Method," International Journal of Advance Research in computer Engineering \& Technology, vol. 1, November, 2012. 